\title{
Effects of corticosteroids in acute severe asthma
}

Most respiratory physicians would subscribe to the view that systemic corticosteroids are essential in the management of acute severe asthma, though there have been dissenting voices. ${ }^{12}$ Studies of asthma deaths have highlighted failure to use systemic corticosteroids as a risk factor for death from asthma. ${ }^{3}$ The recently published guidelines on the management of acute severe asthma emphasise the importance of systemic corticosteroids. ${ }^{4}$ Yet in this issue of Thorax two trials are reported of the use of corticosteroids in acute severe asthma that provide little evidence of any therapeutic effect. ${ }^{56}$ Can the apparent contradiction between the results of these and other trials showing no benefit for steroids in acute severe asthma and the widely held belief that they are essential be resolved? This requires an examination of our understanding of the pathogenesis of acute severe asthma, the mechanism of action of corticosteroids in asthma, and a review of published trials.

\section{Pathophysiology of acute severe asthma}

Concepts of the pathophysiology of chronic asthma have changed in the last two decades. ${ }^{7}$ Asthma is increasingly considered to be a disease of chronic airways inflammation subject to exacerbations caused by viruses, antigens, and non-specific irritants. These exacerbating factors lead to worsening of airways inflammation ${ }^{8}$ and the release of chemical mediators that cause airway smooth muscle spasm. ${ }^{9}$

These basic mechanisms are reflected in the clinical presentation of acute severe asthma. Although some attacks present as sudden wheeze and shortness of breath "out of a clear blue sky," most occur against a background of long term poorly controlled asthma or asthma that has been worsening for some days or even weeks. ${ }^{3}$ The treatment of acute severe asthma is therefore an important occasion to review the management of chronic asthma as advocated in the British Thoracic Society's guidelines. ${ }^{4}$ In the management of chronic asthma the efficacy of treatment with both oral and inhaled corticosteroids is unequivocal. ${ }^{10-15}$ When we are considering the role of systemic corticosteroids in acute severe asthma treatment of the underlying chronic asthma must not be ignored. Whereas the smooth muscle spasm of acute severe asthma may respond to bronchodilators, treatment of the underlying inflammation will largely depend on the use of corticosteroids.

\section{Mechanism of action of corticosteroids}

Corticosteroids have a multitude of actions that may be potentially of benefit in asthma. They decrease inflammatory cell recruitment and activation, ${ }^{16}$ upregulate $\beta_{2}$ receptors, ${ }^{17}$ and decrease microvascular permeability ${ }^{18}$ and they may decrease mucus production. ${ }^{19}$ In terms of molecular mechanism steroids are thought to act by binding to a glucocorticoid receptor, which is then activated and binds to the cell nucleus, on to the regulatory glucocorticoid receptor elements associated with several genes. ${ }^{20}$ These glucocorticoid response elements then up or down regulate production of messenger RNA (mRNA), which eventually leads to increases or decreases in protein production. The proteins affected include enzymes and cell surface receptors. Such a mechanism of action, with gene regulation and then protein synthesis, will obviously take some hours or even days to show a clinical effect. In view of these basic mechanisms early effects in acute severe asthma would not be anticipated.
Trials of corticosteroids in acute severe asthma

The natural history of acute severe asthma leads to either death or resolution. There is usually a natural tendency to improvement. In almost all trials of corticosteroids in acute severe asthma other effective anti-asthma treatment has also been given, including large doses of inhaled $\beta_{2}$ agonists and in many studies intravenous or oral theophyllines. Most patients will already be taking anti-asthma treatment, including inhaled or oral corticosteroids. The effect of corticosteroids has to be seen over and above the natural tendency to improvement and the other effective treatments. There is also evidence for a variability in individual patients' response to corticosteroids, ${ }^{21}$ which is well recognised clinically but will also lead to a scatter of responses in any clinical trial. Furthermore, most trials have followed patients for a short time, rarely exceeding three days and often as little as six hours. Given these factors and the small number of patients in some studies, it is not surprising that some trials have failed to identify a positive effect of corticosteroids.

Morell et al, ${ }^{5}$ in a study of 90 patients split into three groups, have compared two doses of methylprednisolone (60 and $12 \mathrm{mg} / \mathrm{kg} /$ day) with placebo. Patients received a rather unconventional regimen of three doses of adrenaline within the first hour, intravenous aminophylline, and four hourly inhaled hexoprenaline (a $\beta_{2}$ agonist) $5 \mathrm{mg}$. There was no difference in the rate of recovery of pulmonary function or arterial blood gas tensions between the three groups. In two subgroups-those already having oral steroids and those who did not achieve a $15 \%$ improvement in peak expiratory flow by the third hour of the studythere was a trend towards more rapid improvement with very high dose corticosteroids. Twenty eight per cent of patients were taking oral steroids on entry to the study, which may have blunted the ability to show an additional effect of steroids. Furthermore, the concomitant treatment with adrenaline, intravenous aminophylline and $\beta_{2}$ agonists was very vigorous and might have made an additional effect of steroids difficult to detect. Bowler et $a l^{6}$ in a study of 66 patients with acute severe asthma compared three different doses of corticosteroids, but did not include a placebo group. They compared a "low" dose (hydrocortisone 50 mg six hourly), a "medium" dose (200 mg six hourly), and a "high" dose ( $500 \mathrm{mg}$ six hourly) each given for 48 hours. All subjects received inhaled $\beta_{2}$ agonists and theophylline. They showed no difference in the rate of recovery in lung function between the three groups.

Both Morell et $a l^{5}$ and Bowler et $a l^{6}$ have failed to identify a dose-response relationship for corticosteroids in the treatment of acute severe asthma. This finding is similar to the results of other trials, where investigators have been unable to establish a dose-response relationship. ${ }^{22-25}$ Examining these studies in more detail shows that McFadden et al $^{22}$ followed patients for only six hours, which is too short a time to show a significant effect. Other studies with negative results have probably investigated too few subjects, Harfi et $a^{23}$ studying 21 children and Tanaka et $a l^{24} 10$ adults. Raimondi et $a l^{25}$ studied 40 adults, investigating two doses of hydrocortisone $(80$ and $6 \mathrm{mg} / \mathrm{kg} /$ day) over five days, and failed to show a difference. Haskell et al $^{26}$ showed a dose-response relationship for three doses of methylprednisolone, with faster recovery in those having medium and high doses. In a small eight day study of 26 patients by Britton et al there was a tendency for the groups taking medium and high dose steroids to do better than the 
low dose group. ${ }^{27}$ In a crossover study of treatment of deteriorating asthma treated on an outpatient basis an unequivocal dose-response relationship has been shown by Webb. ${ }^{28}$

When trials have compared systemic corticosteroids with placebo they have usually had a positive result. ${ }^{29-32}$ In trials with negative results patients were studied for only six hours ${ }^{22}$ or discharge from the emergency room 12 hours after the start of treatment was the major endpoint. ${ }^{33}$

The various trials have used intravenous hydrocortisone, oral corticosteroids, or both. One study compared oral prednisolone $(75 \mathrm{mg}$ ) plus placebo with prednisolone 75 $\mathrm{mg}$, and intravenous hydrocortisone ( $3 \mathrm{mg} / \mathrm{kg}$ six hourly) and found no difference in peak expiratory flow rate at 24 hours. ${ }^{34}$ This result is predictable from our new knowledge about the absorption of oral steroids and the mode of action of steroids.

It is customary to end a review such as this by calling for further research to be undertaken; but the weight of evidence from clinical trials of steroids in acute severe asthma, the epidemiological studies, ${ }^{3}$ and clinical experience make trials investigating the efficacy of steroid versus placebo and the route of administration difficult to justify. Unresolved questions remain-namely, the dose and the duration of treatment. The trial design used will obviously depend on the question being asked but anyone who is tempted to perform a trial of corticosteroids in acute severe asthma should bear in mind the following: (a) ideally bronchodilator treatment that is in accordance with standard practice should be used in the study; (b) if more than two treatments are compared or multiple groups are used the power of the study will decrease unless numbers are large; $(c)$ the longer the period of observation the better, up to perhaps one week being useful; and $(d)$ including relapse rate after discharge as an endpoint may be helpful.

NC BARNES

London Chest Hospital, London E2 9JX

1 Luksza AR. A new look at adult asthma. Br J Dis Chest 1982;76:11-4.

2 Luksza AR. Acute severe asthma treated without steroids. Br J Dis Chest 1982;76:15-9.

3 Ormerod LP, Stableforth DE. Asthma mortality in Birmingham 1974-7: 53 deaths. $B M J$ 1980;i:687-90.

4 British Thoracic Society. Guidelines for management of asthma in adults: II-Acute severe asthma. BMJ 1990;301:651-4.

5 Morell F, Orriols R, de Gracia J, Curull V, Pujol A. Controlled trial of intravenous corticosteroids in severe acute asthma. Thorax 1992;47: 588-91.

6 Bowler SD, Mitchell CA, Armstrong JG. Corticosteroids in acute severe asthma: effectiveness of low doses. Thorax 1992;47:584-7.

7 Kay AB. Asthma and inflammation. J Allergy Clin Immunol 1991;87: 893-945.

8 Beasley R, Roche WR, Roberts JA, Holgate ST. Cellular events in the bronchi in mild asthma and after bronhial provocation. Am Rev Respir Dis 1989;139:806-17.

9 Taylor GW, Black P, Turner N, Fuller RW, Dollery CT. Urinary leukotriene $\mathrm{E} 4$ after antigen challenge and in acute asthma and allergic rhinitis. Lancet 1989;i:584.

10 Medical Research Council. Controlled trial of effects of cortisone acetate in chronic asthma. Lancet 1956;ii:798-803.

11 Ellul-Micaleff R, Borthwick RC, McHardy GJR. Time course of response to prednisolone in chronic bronchial asthma. Clin Sci Mol Med 1974;47: 105-17.

12 Morrow-Brown H, Storey G, George WHJ. Beclomethasone diproprionate: a new steroid aerosol for the treatment of allergic asthma. $B M J$ 1972;i: a new sterc.

13 British Thoracic and Tuberculosis Association. A controlled trial of inhaled corticosteroids in patients receiving prednisone tablets for asthma. $\mathrm{Br}$ Dis Chest 1976;70:95-103.

14 Toogood JH, Lefcoe NM, Haines DSM. A graded dose assessment of the efficacy of beclomethasone dipropionate aerosol for severe chronic asthma. J Allergy Clin Immunol 1977;59:298-308.

15 Smith MJ, Hodson ME. High dose beclomethasone inhaler in the treatment of asthma. Lancet 1983; i:265-8.

16 Schleimer RP. Effects of glucocorticoids on inflammatory cells relevant to their therapeutic applications in asthma. Am Rev Respir Dis 1990;141: 559-69.

17 Svedmyr N. Action of corticosteroids on beta-adrenergic receptors. Am Rev Respir Dis 1990;141:S31-8.

18 Williams TJ, Yarwood $H$. Effect of glucocorticoids on microvascular permeability. Am Rev Respir Dis 1990;141:S39-43.

19 Lundgren JD, Kaliner MA, Shelhamer JH. Mechanisms by which glucocorticosteroids inhibit secretion of mucus in asthmatic airways. Am Rev Respir Dis 1990;141:S52-8.

20 Munck A, Mendel DB, Smith LI, Orti E. Glucocorticoid receptors and actions. Am Rev Respir Dis 1990;141:S2-10.

21 Corrigan CJ, Brown PH, Barnes NC, Szefler SJ, Tsai J-J, Frew AJ, et al. Glucocoricoid resistance in chronic asthma. Am Rev Respir Dis 1991;144:1016-25.

22 McFadden Jr ER, Kiser R, de Groot WJ, Holmes B, Kiker R, Viser G. A controlled study of the effects of single doses of hydrocortisone on the resolution of acute attacks of asthma. Am J Med 1976;60:52-8.

23 Harfi H, Hanissian AS, Crawford LV. Treatment of status asthmaticus in children with high doses and conventional doses of methylprednisolone. Pediatrics 1978;61:829-31.

24 Tanaka R, Santiago SM, Kuhn GJ, Williams RE, Klaustermeyer WB. Intravenous methylprednisolone in adults in status asthmaticus: comparison of two dosages. Chest 1982;82:438-40.

25 Raimondi AC, Figueroa-Casas JC, Roncoroni AJ. Comparison between high and moderate doses of hydrocortisone in the treatment of status asthmaticus. Chest 1986;89:832-5.

26 Haskell RJ, Wong BM, Hansen JE. A double-blind, randomised clinical trial of methylprednisolone in status asthmaticus. Arch Intern Med 1983, 143:1324-7.

27 Britton MG, Collins JV, Brown D, Fairhust NPA, Lambert RG. High-dose corticosteroids in severe acute asthma. $B M J$ 1976;ii:73-4.

$28 \mathrm{Webb}$ JR. Dose response of patients to oral corticosteroid treatment during exacerbations of asthma. BMJ 1986;292:1045-7.

29 Fanta CH, Rossing TH, McFadden ER Jr. Glucocorticoids in acute asthma, a critical controlled trial. Am J Med 1983;74:845-51.

30 Littenberg B, Gluck EH. A controlled trial of methylprednisolone in the emergency treatment of acute asthma. N Engl J Med 1986;314:150-2.

31 Younger RE, Gerber PS, Herrod HG, Cohen RM, Crawford LV. Intravenous methylprednisolone efficacy in status asthmaticus of childhood. Pediatrics 1987;80:225-30.

32 Lore ML, Chai H, Leung D, Rohr C, Brewer AM. Corticosteroids in the treatment of acute exacerbations of asthma. Ann Allergy 1980;45:67-71.

33 Stein LM, Cole RP. Early administration of corticosteroids in emergency room treatment of acute asthma. Ann Intern Med 1990;112:822-7.

34 Harrison BDW, Stokes RC, Hart GJ, Vaughan DA, Ali NJ, Rcbinson AA. Need for intravenous hydrocortisone in addition to oral prednisolone in patients admitted to hospital with severe asthma without ventilatory failure. Lancet 1986; i:181-4. 